This is an electronic reprint of the original article. This reprint may differ from the original in pagination and typographic detail.

Author(s): Mäkinen, Katja

Title: $\quad$ Union Citizenship Representing Conceptual (Dis)continuities in EU Documents on Citizenship and Culture

Year: $\quad 2014$

Version:

Please cite the original version:

Mäkinen, K. (2014). Union Citizenship Representing Conceptual (Dis)continuities in EU Documents on Citizenship and Culture. Contributions to the History of Concepts, 9(1), 105-120. https://doi.org/10.3167/choc.2014.090107

All material supplied via JYX is protected by copyright and other intellectual property rights, and duplication or sale of all or part of any of the repository collections is not permitted, except that material may be duplicated by you for your research use or educational purposes in electronic or print form. You must obtain permission for any other use. Electronic or print copies may not be offered, whether for sale or otherwise to anyone who is not an authorised user. 


\title{
Union Citizenship Representing Conceptual (Dis)continuities in EU Documents on Citizenship and Culture
}

Katja Mäkinen

University of Jyväskylä

\begin{abstract}
The question in this article is how citizenship is reinvented and recontextualized in a newly founded European Union after the launching of Union Citizenship. What kind of conceptions of citizenship are produced in this new and evolving organization? The research material consists of documents presented by EU organs from 1994 to 2007 concerning eight EU programs on citizenship and culture. I will analyze conceptual similarities (continuities) and differences (discontinuities) between these documents and previous conceptualizations in various contexts, including citizenship discussions in the history of integration since the 1970s as well as theories of democracy and nation-states. Based on the analysis of participation, rights, and identity as central dimensions of citizenship, I will discuss the relationship of Union Citizenship to democracy and nationality.

Keywords

citizen, conceptual change, EU documents, EU programs, Union Citizenship
\end{abstract}

\section{EU Documents and the Conceptual History of Union Citizenship}


The year 2013 was named “The European Year of Citizens” following an initiative by the European Commission from 2010, ${ }^{1}$ simultaneously marking twenty years of the existence of Union Citizenship. In the 1970s and 1980s, the phrase “community citizen” was used, but its use was still arbitrary. "Citizenship” has been used more commonly since the adoption of "Union Citizenship” in the Treaty of Maastricht, signed in 1992. Not a slow conceptual change, Union Citizenship has been a relatively fast conceptual innovation-to the extent that in the rhetoric of many EU texts, “citizens” and “citizenship” are given a very central place as “cornerstones" or "cores” of integration. Thus, it can be said that citizens have risen alongside the member states in terms of integration. The EU, for its part, has become a frame of reference for citizenship alongside the member states. The European Year of Citizens is just one illustration of these developments.

The European Union is a new context for the concept of citizenship, offering an opportunity to study the kinds of conceptual continuities and discontinuities the EU brings about in comparison with earlier usages of the concept of citizenship. The introduction of Union Citizenship can be seen as both a conceptual and a political change and innovation. ${ }^{2}$ Conceptual change is present in the entire history of European integration. One example is the name changes of the integrating polity: the European Coal and Steel Community was founded in 1951, the European Economic Community (EEC) and the European Atomic

1. European Commission, "EU Citizenship Report 2010: Dismantling the Obstacles to EU Citizens’ Rights,” 27 October 2010, COM (2010) 603, accessed 17 March 2014, http://eurlex.europa.eu/LexUriServ/LexUriServ.do?uri=COM:2010:0603:FIN:EN:PDF.

2. Terence Ball, James Farr, and Russell L. Hanson, “Editors’ Introduction,” in Political Innovation and Conceptual Change, Terence Ball, James Farr, and Russell L. Hanson, eds., (Cambridge: Cambridge University Press, 1989), 2. 
Energy Community in 1957, and the European Communities (EC) in 1965. In 1992, the European Union (EU) was founded. These changes in names have often been linked to changes in the forms of integration, illustrating how conceptual change has meant political change. “[P]roducing and sharing common conceptions, imaginings and concepts” is essential for European integration in general. ${ }^{3}$

In his autobiographical book about European integration, one of the founding fathers of integration, Altiero Spinelli, ${ }^{4}$ said that the European community has no already-formulated political language, but would have to invent one. The conceptualization of Union Citizenship is part of this process of inventing a political language for the EU and has been transformed and reinterpreted in the policy documents referred to in this article.

The research material for this article consists of fifty-four policy documents presented by EU organs from 1994 to 2007 concerning five EU programs on culture and three programs on citizenship. ${ }^{5}$ Funding can be requested for citizens’ activity and cultural activity from these programs. The research material includes program proposals made by the European Commission and the decisions about the programs made by the European Parliament or both the parliament and the Council of the European Union together, as well as documents

3. Elina Palola, Näkökulmia eurooppalaiseen sosiaalipolitiikkaan: Malli, väestö, resurssit ja kommunikaatio [Perspectives of European social policy: Model, population, resources, and communication] (Helsinki: Stakes, 2007), 59.

4. Altiero Spinelli, The Eurocrats: Conflict and Crisis in the European Community, trans. Charles Grove Haines (Baltimore: Johns Hopkins University Press, 1966). Originally published 1965 by Rapporto sull’Europa.

5. In this article, only some of these documents are referred to directly. References made to these documents as well as to other EU documents are placed in the footnotes. 
presented by the parliament, the Council of the EU, the Committee of Regions, and the European Economic and Social Committee between the starting and ending points of the process.

The three citizenship programs can be assumed to be key actors in implementing the Maastricht citizenship. In the European Commission's fifth report on citizenship-it was required in the Treaty of Maastricht that the commission report about the application of the Union Citizenship every three years—all the citizenship programs discussed in this article are indeed mentioned as “important instruments to promote active European citizenship” and as a "new boost for the EU fundamental rights and citizenship policies.” ${ }^{6}$ According to the commission, rights are the focus of the Fundamental Rights and Citizenship program, whereas the Europe for Citizens program is said to tackle citizens’ participation in the integration process, European identity, and citizens’ duties. ${ }^{7}$

The programs regarding culture, for their part, are central actors in implementing the common cultural policy launched for the EU in the Treaty of Maastricht. They provide an opportunity to study how citizenship appears in material in which the primary focus is

6. Commission of the European Communities, "Report from the Commission: Fifth Report on Citizenship of the Union,” 15 February 2008, COM (2008) 85 final, accessed 17 March 2014, http://eur-lex.europa.eu/LexUriServ/LexUriServ.do?uri=COM:2008:0085:FIN:en:PDF, 4, 10 .

7. Commission of the European Communities, "Proposal for a Decision of the European Parliament and of the Council Establishing for the Period 2007-2013 the Programme ‘Citizens for Europe’ to Promote Active European Citizenship,” 12 July 2005, COM (2005) 116 final, accessed 17 March 2014, http://eurlex.europa.eu/LexUriServ/LexUriServ.do?uri=COM:2005:0116:FIN:EN:PDF, 2, 28. 
something other than citizenship. In the course of European integration, culture has been seen as a central field of producing citizenship. It has also been formulated as a sphere close to citizens, which can be used for bringing citizens closer to the union and each other and thus building the EU community and promoting integration. In the early 1970s, both citizenship and culture were discussed as solutions for the identity crisis of the EEC. In the People's Europe reports of 1985, which became important milestones in the history of Union Citizenship, cultural factors were discussed in close connection to citizenship. Both citizenship and culture were made official fields of European governance in the Treaty of Maastricht. In the EU documents regarding both citizenship programs and cultural programs, cultural elements are used to define citizenship. In the histories of nation-states, citizenship and culture are tightly intertwined. Both citizenship and culture are crucial for democracy: citizenship is one criterion for democracy and cultural diversity can contribute to the equality required by democracy. Hence, it is interesting to examine how citizenship is discussed in this related but separate policy field.

Earlier documents included in the research material were composed shortly after the Treaty of Maastricht went into effect in 1993, founding the European Union. ${ }^{8}$ These include documents concerning four of the cultural programs (Kaleidoscope, Rafael, Ariane, and Culture 2000). In these early years, the polity called the European Union and the status of Union Citizenship, as well as culture as an official EU policy, were all newly born. Eventually, the concept of Union Citizenship was adopted, ${ }^{9}$ and culture as an official policy

8. Treaty on European Union, Article A, signed at Maastricht on 7 February 1992. Official Journal of the European Communities C 191, 29 July 1992, accessed 15 April 2014, http://eur-lex.europa.eu/legal-content/EN/TXT/PDF/?uri=OJ:C:1992:191:FULL\&from=EN

9. Treaty on European Union, Article 8, Part 2. 
sector of the EU was introduced. ${ }^{10}$ In the documents analyzed in this article, the relationships between citizens and the new polity are negotiated vis-à-vis the citizens.

This might be called a "Maastrichtian moment" and can be viewed as an occasion for innovation and reinvention. ${ }^{11}$ Although concepts usually change constantly and gradually, under the right circumstances, such as during revolutions or in the drafting of a new constitution, concepts are changed instantly through intentional action. ${ }^{12}$ In such moments, opportunities are created for new beginnings and different viewpoints. The Treaty of Maastricht represents such a circumstance. It is as momentous as, for instance, the Magna Carta (1215), the United States’ Declaration of Independence (1776), or the French Declaration of the Rights of Man and of the Citizen (1789), all of which defined the community and its membership in essentially new ways.

The later documents—regarding the Culture program as well as the three citizenship programs, Active European Citizenship, Europe for Citizens, and Fundamental Rights and Citizenship—are linked to two other significant processes. The first is the process of drafting

10. Treaty on European Union, Article 128, Title IX.

11. Terence Ball, James Farr, and Russell L. Hanson, eds., Political Innovation and Conceptual Change (Cambridge: Cambridge University Press, 1989); Kari Palonen, Das “Webersche Moment”: Zur Kontingenz des Politischen [The Weberian moment: On the contingency of the political] (Opladen/Wiesbaden: Westdeutscher Verlag, 1998); J. G. A. Pocock, The Machiavellian Moment: Florentine Political Thought and the Atlantic Republican Tradition (Princeton, NJ: Princeton University Press, 1975).

12. Terence Ball and J. G. A. Pocock, "Introduction," in Conceptual Change and the Constitution, Terence Ball and J. G. A. Pocock, eds. (Lawrence: University Press of Kansas, 1988), 1. 
the Constitutional Treaty in 2005. The EU Constitutional Treaty was not ratified after failing to pass referenda in France and the Netherlands, but many of its formulations were adopted in the Treaty of Lisbon, signed in 2007. The second is the enlargement processes of 2004 and 2007, in which twelve new member states joined the EU. During these processes, the European Union as a community and its legitimation were heatedly discussed and new meanings and definitions emerged.

Thus, all the documents referred to in this article were formulated in situations in which the usage and meanings of concepts were not fixed, but were allowed plenty of leeway for choice and new formulations. William Walters and Jens Henrik Haahr ${ }^{13}$ study the development of the European Coal and Steel Community as a moment in which Europe appears as something particular, as an entity that could become governable in ways that were impossible earlier. In a similar way, introducing Union Citizenship and cultural policy as well as the entire Treaty of Maastricht and later the constitutional and enlargement processes all created opportunities for building a new kind of citizenship, democracy, and political community.

Furthermore, Union Citizenship was adopted in the wider context of what can be called a "renaissance of citizenship”. Since the 1980s, both political interest in and academic research on citizenship increased. This was due to many interrelated processes, such as changes in the role of nation-states, an increase in immigration, a deepening of EU integration, and the development of ideas regarding civil society in the countries belonging to

13. William Walters and Jens Henrik Haahr, Governing Europe: Discourse, Governmentality and European Integration (London: Routledge, 2005), 22-23. 
the former socialist block. ${ }^{14}$ This renaissance meant changes in the settings in which citizenship would be conceived, and an extension of the scope of the concept. In this context, the European Union itself contributed to discussions on citizenship and to increasing interest in citizenship. In this renaissance, new interpretations on rights, participation, and identity were searched and suggested, and the relationship between citizenship and culture was debated. These questions were posed also to Union Citizenship.

In what follows, I will explore the kind of conceptions of citizenship that were produced in EU documents on citizenship and culture from the 1990s and early 2000s. I analyze these conceptions against the discussions on citizenship through the history of European integration since the 1970s, as well as against nation-state citizenship and theories of democracy.

The analysis focuses on two of the four central dimensions of citizenship mentioned in the introduction to this group of articles: rights and the active content of citizenship. In the active content of citizenship I include in this article participation and identity. Identity is a complex term, which for the purpose of this article I define as referring to citizens' identification as a demos capable of using power and making decisions, but occasionally also as a nation sharing cultural background, or, for instance, as political actors in specific matters

14. Jürgen Habermas, "Citizenship and National Identity: Some Reflections on the Future of Europe,” in Theorizing Citizenship, Roland Beiner, ed. (Albany: State University of New York Press, 1995), 255-281; Derek Heater, Citizenship: The Civic Ideal in World History, Politics, and Education (London and New York: Longman, 1995), 293-295; Will Kymlicka and Wayne Norman, "Return of the Citizen: A Survey of Recent Work on Citizenship Theory,” in Theorizing Citizenship, Roland Beiner, ed. (Albany: State University of New York Press, 1995), 283. 
not necessarily bound by territory or culture. Two other dimensions of citizenship mentioned in the introduction are citizens' duties and access to citizenship. In this article, duties are discussed briefly, whereas access is not addressed at all, as only member state nationals are entitled to Union Citizenship.

I will start by pointing to the scarcity of discussions on rights in the EU documents on citizenship and culture in the 1990s and early 2000s. I will show first its continuity and then its discontinuity from the discussions on citizenship in the history of integration. Next, I will focus on the close relationship between citizenship and culture built into these documents, and reflect this with earlier citizenship discussions in the integration history. I will also take note of its similarities with nation-state citizenship. I will then analyze the connections of Union Citizenship with democracy. Finally, I will draw some conclusions concerning what kind of conceptual and political changes are brought about by the uses of the concept citizenship in the EU documents.

\section{Pragmatic Citizenship in Continuity with Special Rights Discourse}

The history of Union Citizenship starts with the discussion of workers' rights in the 1970s. Mobility, economy, private sphere, workers'/citizens' status, and individual freedoms were central elements in those discussions. These elements-familiar from the liberal conceptions

of citizenship ${ }^{15}$ —are still present in the EU documents on citizenship and culture programs of the 1990s and the early 2000s, examined below.

15. Gerard Delanty, Citizenship in a Global Age: Society, Culture, Politics (Buckingham, UK: Open University Press, 2000), 11-22; Peter H. Schuck, “Liberal Citizenship,” in Handbook of Citizenship Studies, Engin F. Isin and Bryan S. Turner, eds. (London, Thousand Oaks, CA, New Delhi, and Singapore: Sage, 2002), 131-144. 
In the history of European integration, citizenship was put on the agenda during the identity crisis of the EEC in the early 1970s. Decreased public support created a need to replace the functionalist model of integration with a new type of integration and with the development of a "European identity”, ${ }^{16}$ Discussions on citizenship centered on rights, which were seen as a way to produce a sense of belonging and identity. ${ }^{17}$ "European identity” was believed to have developed from the feeling that in another member state citizens are treated in a similar way as the nationals of the country in question. Those rights were called "special rights."18

The idea of special rights has its background in the principle of nondiscrimination formulated in the Treaty of Rome (1957), according to which all nationals of member states must be treated equally in every member state irrespective of their nationality. In the special rights discourse, ideas on identity, the principle of nondiscrimination, and rights were intertwined in order to ensure the core principles of integration: free movement of persons, services, capital, and goods.

The history of Union Citizenship can be seen as a series of suggestions to facilitate mobility and to solve problems arising from mobility in the domains of both political rights and everyday life. This kind of pragmatic framing formulates citizenship as a narrow and

16. For instance, “Dokument über die Europäische Identität,” Bulletin der Europäischen Gemeinschaften 12 (1973): 131-134.

17. Antje Wiener, “European” Citizenship Practice: Building Institutions of a Non-state (Boulder, CO, and Oxford: Westview Press, 1998), 63-69.

18. Siofra O’Leary, The Evolving Concept of Community Citizenship: From the Free Movement of Persons to Union Citizenship (The Hague: Kluwer Law International, 1996), 19; Wiener, “European” Citizenship Practice, 89-93. 
noncontradictory concept referring primarily to a private status. Recurrent themes in the discussions on citizenship in the 1970s, as well as in later decades, were the detaching of citizenship from nationality, rights as the core of citizenship, and the connections between rights and economy. ${ }^{19}$

Discussions on citizenship continued in 1985 in two reports prepared by the People's Europe committee. ${ }^{20}$ These reports played important role in the development of Union Citizenship. The suggestions of the committee in the first report continued earlier discussions on special rights based on mobility rights as well as the uniform European passport. They were regarded as measures touching on citizens’ everyday lives and, as such, creating European identity. Again, a conception of a mobile citizen was the focus. In the committee's second report, attention was also paid to political rights, mainly, electoral rights, mentioned already in the discussions of the 1970s. ${ }^{21}$ The People's Europe reports list practically all the rights that were later adopted in the Article 8 of the Treaty of Maastricht.

In the citizenship and culture programs of the 1990s and early 2000s, references to rights related to mobility and nondiscrimination can also be found, even though the discussion of rights is markedly scarce. Citizenship in general is understood as a pragmatic status at the individual level promoting the freedom of mobility. As such, it indicates continuity with the special rights discourse of the 1970s. This is most clear in the documents

19. For instance, O’Leary, The Evolving Concept of Community Citizenship. 20. Adonnino, Pietro, “A People’s Europe:Reports from the ad hoc Committee” Bulletin of the European Communities, Supplement 7/85, accessed 15 April 2014, http://aei.pitt.edu/992/1/andonnino_report_peoples_europe.pdf 21. O’Leary, The Evolving Concept of Community Citizenship, 18; Willem Maas, Creating European Citizens (Lanham, MD: Rowman \& Littlefield, 2007), 31. 
concerning the program on Fundamental Rights and Citizenship and in their discussions regarding the area of freedom, security, and justice. According to them, the principle of free movement and "[ $\mathrm{t}]$ he creation of a Europe for citizens" required that "borders between countries should no longer constitute an obstacle to the settlement of civil and commercial law matters or to the bringing of court proceedings and the enforcement of decisions.” ${ }^{22}$

Mobility and cross-border cooperation are key words in all the other programs, too. The understanding of citizenship as mobility is so dominant in the documents that it almost hides other aspects of citizenship. Strong emphasis on mobility connects Union Citizenship to the economy. This, together with articulating Union Citizenship as a formal, private status (rather than as an agency), implies continuity with liberalist conceptions of citizenship, according to which the state should ensure individual freedoms.

\section{Silenced Rights Break Away from the Special Rights Discourse}

An important finding in the EU documents on citizenship and culture programs in the 1990s and early 2000s is, however, that rights are hardly mentioned. Whenever rights are mentioned, they are discussed along the lines drawn in the 1970s, connecting rights with mobility and economic activity, as described above. Yet the number of times rights are mentioned in the program texts is so minuscule that it can be interpreted that they signify a notable discontinuity from the discourse on rights through which Union Citizenship had been developed since the early 1970s until the writing of the founding treaties of the European Union.

22. Commission of the European Communities, "Proposal for a Council Decision Establishing for the Period 2007-2013 the Specific Programme 'Fundamental Rights and Citizenship' as Part of the General Programme 'Fundamental Rights and Justice', 6 April 2005, COM (2005) 122, accessed 15 April 2014, http://eur-lex.europa.eu/legal-content/EN/TXT/PDF/?uri=CELEX:52005PC0122(02)\&rid=5 , 4. 
This discontinuity from the special rights discourse of the 1970s and 1980s is all the more surprising because in the EU documents discussed here there is normally a strong correlation with other EU documents. For instance, the opening chapters of many documents are full of references to earlier EU texts. Even though the Treaty of Maastricht is the basis for Union Citizenship, the program texts are unexpected consequences of it as well as the later treaties, in which rights serve as the foundation of Union Citizenship. This level of inconsistency is, however, typical of administrative assemblages, ${ }^{23}$ in which various elements are combined in one text.

In the citizenship and culture documents, there is nearly no discussion of political rights or social rights, including cultural rights. Fundamental rights and mobility rights in particular are mentioned more often. The documents continue to develop the conception of citizenship—-familiar from the early history of EU citizenship—according to which citizens are regarded as targets to whom the same rights and freedoms of mobility must be granted in all the member states. Citizens are, however, not seen as active users of rights. The actor in EU documents is often the European Commission or the proposed program, whereas citizens are the recipients of these actions. The documents thus follow the top-down pattern, common in the integration history, of introducing first rights and then status of citizenship without citizens’ strong contribution.

\section{Cultural Citizenship Continuing from the People's Europe Discourse and from National}

\section{Citizenship}

23. Janet Newman and John Clarke, Publics, Politics and Power: Remaking the Public in Public Services (London: Sage, 2009), 26. 
Alongside citizenship, culture was seen as a solution for the EEC's identity crisis in the early 1970s. In addition to the special rights discourse and the uniform passport, a more abstract sense of belonging was discussed as an element of identity. The significance of culture for integration was acknowledged as early as the 1960s and 1970s, and the summits held in Paris in 1972 and 1974 started the discussions on citizenship outside the economic context. ${ }^{24}$

Culture was very prominent in the second People’s Europe report written in 1985. In this report, culture—meaning symbols, artistic events, cultural heritage, everyday life—was introduced as a new element in the relationship with the European community alongside rights. The documents on citizenship and culture programs in the 1990s and 2000s follow the instructions given in the People's Europe reports: the EU should be seen and felt concretely in citizens' daily lives.

\footnotetext{
ACTION 3: Together for Europe

High-visibility events

This measure will support events ... which are substantial in scale and scope, strike a chord with the peoples of Europe, help to increase their sense of belonging to the same community, make them aware of the history, achievements and values of the
}

\footnotetext{
24. O’Leary, The Evolving Concept of Community Citizenship, 18; see also Cris Shore and Annabel Black, “Citizens’ Europe and the Construction of European Identity,” in The Anthropology of Europe: Identities and Boundaries in Conflict, Victoria A. Goddard, Josep R. Llobera, and Cris Shore, eds. (Oxford and Washington, DC: Berg, 1996), 275-276.
} 
European Union, involve them in intercultural dialogue and contribute to the development of their European identity. ${ }^{25}$

In these documents, like in the earlier People’s Europe discourse, citizenship and culture—-both defined as European—are discussed together, and they are both seen as instruments for "bringing Europe closer to citizens”. To this end, symbols are important in the same way they were important in the People’s Europe report. Citizenship is understood as cultural identity, unity, and belonging to a community. As such, citizenship appears to be membership in an "ethnos” kind of community rather than in a demos. The close connection of citizenship with cooperation, community, and identity defined with cultural elements represent continuity with communitarian traditions of citizenship as acting together, personal contacts, and membership in a community.

This usage of citizenship can be connected with the tradition derived from nationstates. It is common to both the EU documents and classical nation-state conceptions to articulate close relations between citizenship, culture, and territory, and all of these are connected with community construction and legitimation. Typical of the EU’s “cultural construction" in these documents as well as in other arenas is the idea of "unity in diversity":

25. "Decision No 1904/2006/EC of the European Parliament and of the Council of 12 December 2006 Establishing for the Period 2007 to 2013 the Programme 'Europe for Citizens’ to Promote Active European Citizenship,” Official Journal of the European Union L 378, 27 December 2006, 39, accessed 15 April 2014 http://ec.europa.eu/citizenship/pdf/lexuriserv_en.pdf 
Promoting cultural and linguistic cooperation and diversity thus helps to make European citizenship a tangible reality by encouraging direct participation by European citizens in the integration process. ${ }^{26}$

The general objective of the Programme shall be to enhance the cultural area shared by Europeans and based on a common cultural heritage through the development of cultural cooperation between the creators, cultural players and cultural institutions of the countries taking part in the Programme, with a view to encouraging the emergence of European citizenship. ${ }^{27}$

Connecting citizenship to culture and constructing them as "European” makes Union Citizenship look like nationality. Union Citizenship does not necessarily mean to do something but rather to be "European". Citizenship constructed in the documents is thus nation-state-like to some extent. It does not appear as a completely new, postnational citizenship, as is sometimes suggested.

\section{A Break from Concepts of Democracy and Political Agency}

26. Commission of the European Communities, "Proposal for a Decision of the European Parliament and of the Council Establishing the Culture 2007 Programme (2007-2013),” 14 July 2004, COM (2004) 469, accessed 17 March 2014, http://eur-lex.europa.eu/LexUriServ/LexUriServ.do?uri=COM:2004:0469:FIN:EN:PDF, 10; "Decision No 1855/2006/EC of the European Parliament and of the Council of 12 December 2006 Establishing the Culture Programme (2007 to 2013),” Official Journal of the European Union L 372, 27 December 2006, accessed 15 April 2014 http://eur-

lex.europa.eu/LexUriServ/LexUriServ.do?uri=OJ:L:2006:372:0001:0011:EN:PDF, 1.

27. “Decision No 1855/2006/EC,” 4. 
According to many theories of democracy, the idea of citizenship is inherent to democracy. ${ }^{28}$ But the EU documents analyzed here demonstrate a break from this conception, particularly from republican theories of democracy, according to which participation in decision making is the core of citizenship. Citizenship and democracy are seldom discussed together in the program texts. In that, they differ from the founding treaties of the EU, in which Union Citizenship includes electoral rights at the EU level and at the local level. The absence of the term “democracy” contradicts the programs' names and their explicit aims, which call for active citizenship and citizens’ involvement in integration.

The European Union is often perceived as a distant bureaucracy by its citizens, and, according to the EU documents, Union Citizenship could be a solution for this problem. It is possible to interpret Union Citizenship as a remedy for the democracy deficit of the EU. My reading does not support this interpretation. The EU and its rights of citizenship have also been seen as opportunities for developing non-national democracy, ${ }^{29}$ but in the EU documents examined here, they are not developed as such. The citizenship discussions of the EU documents differ also from various programs of democracy education or citizenship education developed by different levels of administration, such as the Council of Europe or the United Nations.

28. For instance, Robert Dahl, On Democracy (New Haven, CT, and London: Yale University Press, 1998), 83-98.

29. Gerard Delanty, Inventing Europe: Idea, Identity, Reality (London: MacMillan Press, 1995), 156-163; Gerard Delanty, Citizenship in a Global Age: Society, Culture, Politics (Buckingham, UK, and Philadelphia: Open University Press, 2002), 110-120; Yasemin Nuhogly Soysal, “Changing Citizenship in Europe,” in Citizenship, Nationality and Migration in Europe, Mary Cesarani and David Fulbrook, eds. (London: Routledge, 1996). 
Citizens' chances to use power are not emphasized even in the documents' discussions of participation. Direct participation in decision making at the EU level or other levels is not much discussed. Citizens’ participation is channelled into two arenas: EU programs and "European construction": "The programme will foster the direct participation of citizens across Europe, both in the activities of the programme and in the development of the notion of a European identity." 30 "European construction” is a phrase often used in "EUspeak”. In these documents, it refers to “constructing an ever-closer Europe”-following the Treaty of Rome-as well as developing "the notion of a European identity” or simply "European integration”. Participation in EU programs can be seen as one part of this “European construction”. Thus, the discussions follow Jean Monnet's ${ }^{31}$ view that integration proceeds through small groups, connections, and cooperation.

In order to bring Europe closer to its citizens and to enable them to participate fully in the construction of an ever closer Europe, there is a need to address all citizens and to involve them in transnational exchanges and cooperation activities, contributing to the forging of a sense of belonging to common European ideals. ${ }^{32}$

30. Commission of the European Communities, "Proposal for a Decision of the European Parliament and of the Council Establishing for the Period 2007-2013 the Programme 'Citizens for Europe',” 4, 29.

31. Jean Monnet, Memoirs, trans. Richard Maine (London: Collins, 1978), originally published 1976; see also Walters and Haahr, Governing Europe, 28-31.

32. Commission of the European Communities, "Proposal for a Decision of the European Parliament and of the Council Establishing for the Period 2007-2013 the Programme 'Citizens for Europe’,” 9. 
The programme shall contribute to the following general objectives: giving citizens the opportunity to interact and participate in constructing an ever closer Europe, which is democratic and world-oriented, united in and enriched through its cultural diversity, thus developing citizenship of the European Union. ${ }^{33}$

There is nearly no explicit discussion concerning citizens' duties in the documents, but both mobility and the participation in the integration process are represented as citizens' duties in order to promote integration.

[C]itizens should also be aware of their duties as citizens and become actively involved in the process of European integration, developing a sense of belonging and a European identity. ... The European Union therefore requires a programme which puts citizens at the centre, which offers them the opportunity to fully assume their responsibilities as European citizens and which responds to the need to improve their participation in the construction of Europe. ${ }^{34}$

The significance of citizens' participation in integration is emphasized, as if the citizens were responsible for integration. This kind of rhetoric links EU documents' arguments to new

33. “Decision No 1904/2006/EC,” 34.

34. Commission of the European Communities, "Proposal for a Decision of the European Parliament and of the Council Establishing for the Period 2007-2013 the Programme 'Citizens for Europe',’' 2. 
governance, in which the aim is often to involve citizens in helping administration rather than activating them in decision making.

Citizenship has traditionally been understood in an Aristotelian sense as using power in public matters, but a conceptual change toward individualization and privatization, as part of the trend touching many fields since the 1980 s, can be recognized. ${ }^{35}$ In the EU documents, attaching citizenship discursively to the individual rather than to democratic action reflects this shift. Is being together and sharing the same status all that is left of citizenship in this phase of capitalism and liberalism?

The unspecific and individualized usage of citizenship in EU documents can hence be regarded as being part of a broader erosion of the concept of citizenship. The documents show their connection to this trend, in which the concept of citizenship has become more common and the scope of the concept extended. If citizenship is understood as a term with which the administration is addressing its subjects, or as an activity that increases social capital, it may cease to be a way through which citizens can make demands. With these kinds of conceptual choices the attention is directed away from citizenship as political agency in the EU documents analyzed here.

The scarcity of connections made between citizenship and politics, power, decisionmaking, public activity, or democracy in the EU documents thus show a break away from a

35. Ulrich Beck, “The Reinvention of Politics: Towards a Theory of Reflexive Modernization," in Reflexive Modernization: Politics, Tradition and Aesthetics in the Modern Social Order, Ulrich Beck, Anthony Giddens, and Scott Lash, eds. (Oxford: Blackwell, 1995), 13-21; Ulrich Beck and Elisabeth Beck-Gernsheim, Individualization: Institutionalized Individualism and its Social and Political Consequences (London, Thousand Oaks, CA, and New Delhi: Sage, 2006). 
conception of citizenship as political agency. Participation, identity, and rights are all deeply political dimensions of citizenship, but in the EU documents on citizenship and culture from the 1990s and early 2000s, they are not presented as such.

Another sign of divergence from the political understanding of citizenship concerns diversity, which both politics and democracy require. Questions of diversity often come up in academic as well as other discussions on citizenship, especially since the "renaissance of citizenship” in the 1990s. The European Union is a diverse community, and diversity is one

of its slogans. Indeed, in the EU documents, diversity is mentioned as a value. ${ }^{36}$ However, it is not connected to citizenship through, for instance, discussions on minority rights or cultural rights. Instead, differences are blurred, and citizens are seen as members of the EU community, as “us”. This kind of top-down "we-speak” does not necessarily enhance diversity.

\section{Union Citizenship Representing Conceptual and Political Change}

In the EU documents of the 1990s and early 2000s on citizenship and culture programs, one can trace both continuities and discontinuities with previous discourses in the integration process as well as in academic discussions on citizenship. I have shown that Union Citizenship can be seen both as continuing from and breaking from the special rights discourse of the 1970s. In the understanding of citizenship as a private status attached to

36. "Decision No 508/2000/EC of the European Parliament and of the Council of 14 February 2000 Establishing the Culture 2000 Programme,” Official Journal of the European Union L 63, 10 March 2000, accessed 15 April http://ec.europa.eu/culture/archive/sources_info/pdf-word/decision_en.pdf , 5, 6; “Decision No 1904/2006/EC,” 32, 34; “Decision No 1855/2006/EC,” 1, 8. 
economic activity, continuity with liberalist views on citizenship can be seen. The documents also continue the tradition of connecting citizenship and culture with each other present in the People’s Europe reports of 1985. Thus, we can see a continuation of both communitarian and nation-state citizenship. Citizenship is not strongly linked with democracy, which suggests a break from understandings of citizenship as one criterion for democracy and particularly from republican notions of citizenship as well as from conceptions of citizenship as political agency. The strong emphasis on citizens’ participation in EU programs and in EU integration can be interpreted as continuing with the Monnet method in the history of integration as well as more recent ideas of new governance. The EU documents can be seen to present continuity with the trends of broadening the scope of the concept of citizenship. They also continue the general tendencies of individualization and privatization.

In the documents reviewed here, explicit references are made to other EU documents, especially to the founding treaties and summit declarations. Through these references, a story about the EU as a community is told. Some of the formulations of the documents, however, are unexpected. Even though the contents of the concept of citizenship remains unclear in the documents, the affluent and all-embracing usage of it manifests that citizenship is regarded as a key concept with many positive connotations —-with equality, community, and democracy, for instance. But though EU documents mostly use a positive and optimistic rhetoric, citizenship formulations are modest in them. EU documents show a strong belief in common culture and in the success story of integration, but not in citizens' chances to use power. They declare big principles and best practices, but provide no credible instruments for increasing democracy.

Conceptual changes are ongoing processes without final endings and fixed meanings. Union Citizenship is a good example of how political changes and conceptual changes intertwine. Discussions on Union Citizenship can be interpreted as transition processes in 
which conceptual and political changes occur at different paces. Union Citizenship as a concept has been a reaction to changes in political reality, because it aimed at answering problems concerning mobility. In this case, the development of Union Citizenship appears to follow political change. Here Union Citizenship can be interpreted as a concept that has remained unchanged, but the content of which has changed to some extent in the discussions on EU integration. ${ }^{37}$

Union Citizenship can, however, also be interpreted as a conceptual change that occurs before or without any political change. ${ }^{38}$ The concept of Union Citizenship has been coined, but it does not yet have a full-fledged equivalent in political reality. In EU documents, the concept is not given practical content, such as citizens' political action.

Finally, the discussions of citizenship in EU documents can be seen as the action of innovative ideologists, ${ }^{39}$ aimed at changing the concept of citizenship by emphasizing some aspects of it over others. In this case Union Citizenship can be considered an example of

37. Heiner Schulz, "Begriffsgeschichte und Argumentationsgeschichte” [Conceptual history and argumentation history], in Historische Semantik und Begriffsgeschichte [Historical semantics and conceptual history], Reinhart Koselleck, ed. (Stuttgart: Klett-Cotta, 1979), 65; Reinhart Koselleck, Begriffsgeschichten: Studien zur Semantik und Pragmatik der politischen und sozialen Sprache (Frankfurt am Main: Suhrkamp Verlag, 2006), 62.

38. Schulz, “Begriffsgeschichte und Argumentationsgeschichte,” 66; Koselleck, Begriffsgeschichten, 62.

39. Quentin Skinner, Visions of Politics, vol. 1, Regarding Method (Cambridge: Cambridge University Press, 2002), 149-150. 
Reinhart Koselleck’s Vorgriff-a future-oriented concept that can be used as an instrument for change. ${ }^{40}$

Ball, Farr, and Hanson state that "conceptual cum political change" is at the same time critical, creative, and conservative. ${ }^{41}$ The critical element in the discussions on citizenship in the EU documents is-according to the definitions given by Ball, Farr, and Hanson - the documents’ aim to bring new order to moral and political spheres by transferring the concept of citizenship into a new context. The category of citizenship is seen in the documents as useful for the EU, and thus the target of the critique is the fact that citizenship belongs in the domain of the nation-state.

The creative element mentioned by Ball, Farr, and Hanson as one feature of the “conceptual cum political change” is also present here. ${ }^{42}$ The EU documents’ discussions on citizenship show creativity and argumentative and rhetorical skills in that Union Citizenship is represented as self-evident, natural, and unproblematic, with little room for interpretations, conflicts, or alternatives. This is typical for administrative texts in general.

The meanings given to citizenship are not, however, particularly creative. In situations in which many choices would have been possible—such as at the "Maastrichtian moment" and in the constitution drafting and enlargement processes, in the middle of the "renaissance of citizenship”- - new conceptions were not created. Union Citizenship was not created as an instrument for developing new kinds of citizenship, and thus has a conservative element, as mentioned by Ball, Farr, and Hanson. Rather, citizenship in its familiar form in other contexts is transformed and varied and used in—at least implicit—relation to earlier conventions.

40. Koselleck, Begriffsgeschichten.

41. Ball, et al., “Editors’ Introduction,” 3-4.

42. Ibid. 
Although it appears that citizenship is depoliticized in the EU documents, it is worth remembering that political agency may exist beyond the documents' formulations. As Mitchell Dean notes, administrative rationality aims at regulating politics. ${ }^{43}$ In administrative documents, issues are inclined to be depoliticized. However, citizens may repoliticize concepts of citizenship and community even when these seem apolitical.

43. Mitchell Dean, Governmentality: Power and Rule in Modern Society (London: Sage, 1999), 198. 